\title{
GTE Union Organization - A Case Study
}

\author{
Russell K. Baker, (E-mail: rbaker1@ju.edu), Jacksonville University
}

\section{INTRODUCTION}

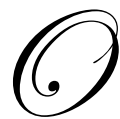

n November 19, 1993 the following notice was sent to the office of the general manager of GTE Supply Company in Tampa, Florida:

Gentlemen:

A petition for certification as collective bargaining representative of certain of your employees has been filed with this office, pursuant to the Labor Management Relations Act, as amended. A copy of the petition is enclosed. Should you desire further information before a Board Agent communicates with you, telephone or write the office to which the case is being assigned, referring to the above case name and number" (United States of America, 1993).

This letter was the beginning of the final phase of long-term labor unrest at GTE Supply. The labor conflict began over five years earlier, and culminated in a third union representation election in January 1994.

\section{HISTORY}

The GTE Supply (GTES) operations in Tampa, Florida were established as a support and logistics center for General Telephone Company's (TELCO) Southeast operations in 1988. GTES was an independent subsidiary corporation to General Telephone, with its headquarters in Dallas, Texas. GTES had logistics centers similar to the Tampa operation throughout the country.

GTE Supply's Tampa operations were housed in a building owned by the former GTE Florida Company (General Telephone - Telco, now Verizon), the Tampa Bay area's local telephone company. The facilities were shared with Telco operations and GTEC (GTE Communications - a Telco subsidiary that retails telephone electronics products to the public).

In February 1994, GTES had approximately 70 bargaining unit employees and 18 exempt employees. Joe Buchanan managed the facilities. Buchanan was with GTE for over 20 years, and had been GTES manager since December 1992. GTES was established to perform the purchasing and distribution function for switches, cable, and other equipment to TELCO. The Tampa operations were established as a nonunion facility. However, many of the original employees of GTES had transferred from TELCO and were former union members. At the time of the transfer the wage scales in TELCO and GTES were approximately the same for equivalent positions.

On January 6, 1993 a representation election in response to the previously mentioned petition was held by the National Labor Relations Board to determine if the International Brotherhood of Electrical Workers (IBEW), Local 824, would represent the bargaining unit employees of GTES. This was the third time since the founding of the Tampa facility that there had been an IBEW representation election. The results of the two previous elections were as follows:

$$
\begin{array}{lll}
1989 & \text { - Votes Against Union - } 32 & \text { Votes for Union - 28 } \\
1990 & \text { - Votes Against Union - 46 } & \text { Votes for Union - 16 }
\end{array}
$$

The results of the third election were markedly different. The union won the election, forty votes in favor of IBEW representation to 28 votes against (United States of America, 1994) 


\section{OBJECTIVES}

This paper will attempt to accomplish two tasks: First, to analyze why the third organizational drive on the GTES Tampa operations was successful after the IBEW lost two previous elections. Second, to simultaneously describe and analyze the campaign and election process for this election as it relates to standard NLRB procedures. Discussing the general procedures of the union organization process, then relating the actual events that transpired during the GTES campaign from the viewpoints of both parties to the campaign, GTES management and IBEW leadership will accomplish this.

\section{THE UNION ORGANIZATION PROCESS}

A campaign begins when a union targets a business through its employees or, as was the situation at GTES, when disgruntled employees contact a union to initiate an organization drive. The employees then seek to get union authorization cards signed by $30 \%$ or more of the members of the bargaining unit (all employees who may be represented by the union), or, if between $30 \%$ or more of the members of the bargaining unit sign authorization cards the employees may petition the National Labor Relations Board (NLRB) to hold a representative election. If over $50 \%$ of the members of the bargaining unit sign authorization cards, the union may request recognition from the company, an option seldom accepted by an organization (Morehead, 1990).

If the company grants recognition, collective bargaining begins. If the company rejects recognition, the employees petition the NLRB for an election as indicated above. Once the NLRB receives a petition, the agency reviews the case for the following criteria:

1. The employer's operations involve interstate transportation as defined in the National Labor Relations Act.

2. There exists a legal question about union representation to be resolved to ensure no union already represents the employees and is protected by the contract bar rule.

3. The bargaining unit proposed is appropriate.

4. The petitioning union has authorization cards signed by a minimum of $30 \%$ of the members of the bargaining unit (Hughes, 1979). If an insufficient number of cards have been signed, the employees may seek to get additional signatures. If the petition meets the above criteria, the NLRB will hold a union representation election of the entire bargaining unit. Upon completion of the representation election, if votes for the union exceed $50 \%$, union bargaining begins. If the bargaining unit rejects union representation, additional union representation elections, by any union, are barred for one year.

\section{THE UNION'S SIDE}

The International Brotherhood of Electrical Workers is an international union affiliated with the AFL-CIO. The IBEW represents both craft and industrial workers employed in jobs related to electrical or electronic industries or crafts. The four locals in Tampa represent individuals ranging from craft electricians in the construction industry to telephone installers and repair people.

Local 824 of the IBEW is located at 6603 E. Chelsea Street in Tampa. Guy Langlais, the union's business manager and president, met with the author on February 2, 1994 to discuss the events leading up to the election of the IBEW as the representative agent for the negotiating unit at GTES.

Local 824 was the bargaining agent for approximately 6,000 employees of Telco and another 400 at GTEC. Mr. Langlais believed that the union - company relationship between the IBEW and GTE had developed into a non-adversarial one over the many years the IBEW has represented GTE employees. To support this claim, he cited the following successful joint company/union efforts: 
1. The 1993 United Way fund drive, sponsored and promoted jointly by the union and the company, raised in excess of $\$ 1,000,000$ from GTE employees. This included members of the bargaining unit as well as exempt employees.

2. Team Incentive Performance Plan - a joint IBEW/GTE total quality management program designed to promote the following concepts:

a. The company and union worked together to concentrate on methods of growing the business rather than shrinking costs through downsizing. To achieve this goal a joint union/management team has been established between GTE and the IBEW.

b. To facilitate the growth of the company and promote the welfare of the bargaining unit, the company and union focused on establishing and maintaining a harmonious relationship.

c. The union provided a service to the company by acting as a training agent for union members. Through an active member-training program, the IBEW was able to keep skill levels abreast of technology and provide GTE employees qualified in for other jobs. This assisted both the company and employees by reducing layoffs and cutbacks.

3. The union had a responsibility to the company as well as to the bargaining unit. A successful business was in everyone's best interest and the union provided whatever assistance to the business it could without jeopardizing the rights of the bargaining unit.

4. The IBEW, working with GTE, had established a health care center in Tampa for GTE employees to help contain rising medical costs for the company while still providing quality medical services to GTE employees (Langlais, February 2, 1994)

Regardless of the degree of harmony between the IBEW and GTE, Mr. Langlais was emphatic that the union's first responsibility was to its membership. He recognized that the union was a business that functions similarly to any other business. However, he stressed that the union provided a necessary service to its members, a service unavailable to them without a union. Through union membership, he said the individual employees were on a stronger, more equal footing with management to negotiate their "fair share" of the profits generated from their labors (Langlais, 1994).

Mr. Langlais stated that for a union organization drive to be successful, the union must educate the employees about unionization and the rights under the National Labor Relations Act. He believed that most nonunion employees did not understand the rights and protection granted by the act. To correct this problem, the IBEW established their MEMO Program to educate potential union members on their rights. MEMO, an acronym for Membership Education and Mobilization for Organizing, is a five-part program designed to be presented to employees during the union organization drive (IBEW MEMO, 1994) A copy of the MEMO Program is in Appendix Two-A.

Failure to educate the employees was the main reason he believed the union lost the organizational drives in 1989 and 1990. Consequently, the MEMO Program was a major component of union strategy during the 1993/1994 drive.

From the union's viewpoint, the 1993/1994 campaign and election was a continuation of efforts to organize GTES since its formation. As stated previously, many of the original employees of GTES were union employees transferred from TELCO. This gave the union the core group it needed to start the first organization drive. Although the union lost the first drive, the close vote provided the incentive to try again the following year. Using what Langlais described as "scare tactics", management inspired another defeat of the union by a much more substantial margin. The scare tactics referred to included management raising issues like dues check off and third party outside intervention (Langlais, 1994). From a management perspective, however, this is considered to be explaining both sides of the issue.The 1993/1994 campaign began in earnest when two influencing factors occurred during 1993. First, ten members of the TELCO bargaining group were transferred to GTES as nonunion employees during January 1993. This was part of a general downsizing program throughout GTE operations. To be fair to the employees, they were transferred at the wage rate they had at TELCO. However, by this time the union wage scale at TELCO had surpassed the nonunion wage scale at GTES. Therefore, the employees who were transferred in were making substantially more money than other employees who had been employed there much longer. Second, later in the year the union and TELCO concluded negotiations on a new threeyear contract for the bargaining group. The new contract provided many improvements over the old contract for the bargaining unit and greatly enhanced the stature of the IBEW local and Langlais in the eyes of both the union members and the nonunion employees. 
After the conclusion of the contract negotiations, several of the GTES non-union employees approached Langlais individually to discuss the possibility of the IBEW instituting another organization campaign for them. Recognizing the opportunity created by the newly transferred employees and new contract, Langlais gave authorization cards to the people who contacted him for distribution among the GTES workers.

The next step for Langlais and the union was the establishment of a core committee of GTES employees to give the union constant representation at the work site and to increase the bond between the employees and the union. The core committee was comprised of the employees who had originally contacted the union and several others who they recommended. The members of the core committee were provided authorization cards and handouts for distribution among their coworkers. To protect the core committee from possible retribution from management, both the company and the NLRB were notified about the union drive and given a list of the committee members. Although this notification had an element of risk associated with it, Langlais based his decision on the following factors:

1. Most of the core committee was comprised of former union members from other GTE companies, and management already knew they supported the union.

2. Notification of both the NLRB and the company would help insure NLRB support in the event any committee members were terminated from their jobs.

3. GTE is a major public service business in the area and could not afford the adverse publicity that could be generated if they terminated union organizers, especially if the union could prove the company knew who the organizers were.

In addition to the notification, the union held training sessions with the core committee members to instruct them on their protected rights under the National Labor Relations Act. During these sessions the employees were warned against committing any unfair labor practices, and instructed to make sure they did not give management any legitimate reason for termination through poor work habits, poor performance or confrontation with supervisors. The core committee at GTES was comprised of sixteen members, all of whom were volunteers. The large number of individuals willing to risk participation in this committee indicated to Langlais a probability that much greater support for organization was present at GTES than existed during the two previous elections.

After the core committee was established, the next step was to arrange a series of informational meetings for all GTES employees. It was during these meetings that the MEMO Program discussed earlier was implemented. Overhead transparencies of each page of the program were presented during the meetings, along with detained explanations and a question session. Employees were given copies of some of the charts and questionnaires to take with them to show others. The meetings were held in the union hall or in employees' homes and typically lasted two to three hours. Although initial attendance was small, only eight people at the first meeting, attendance at subsequent meetings grew to over forty. Langlais believes nearly every GTES employee attended at least one meeting, and most employees attended several. After a sufficient number of employees signed authorization cards, a petition for a representation election was filed with the NLRB by the IBEW (form NLRB-502, Petition, Appendix One, page 4). Although signatures of only 30 percent of the employees are required to petition, IBEW standards preferred at least 55 percent before a petition is presented. This is consistent with many other unions. "Most organizers will wait to announce that the union represents a majority until over 50 percent, and usually 60 to 80 percent, have signed cards" (Jennings, 1991). The petition indicates the company name and address, describes the present bargaining unit composition and number, and certifies that over 30 percent of that bargaining unit have signed authorization cards (United States of America, 1995). The signed cards are presented to the NLRB regional office along with the petition. Unless an unfair labor practice was filed, the NLRB will investigate the petition for both the validity of the signatures on the cards and the appropriateness of the bargaining unit.

Once the petition was filed, the union side of the campaign was relatively straightforward. On December 20, 1993, Langlais sent all the members of the bargaining unit a letter comparing union benefits and wages with nonunion benefits and wages. The letter included several charts and articles supporting the union position. The letter was not a request to vote for the union, but rather a stated "When you vote to join Local 824...." (Langlais, 1993). According to Langlais, this positive, upbeat attitude was maintained by the IBEW throughout the entire campaign. In a second letter, which was sent to the employees on January 3, 1994, Langlais compared management promises made since the 
establishment of GTES with actual management actions. He simply stated that "They did not keep their promises" (Langlais, January 3, 1994), and supported this claim by providing copies of three communications from management to the employees with the implication that the promises made in these letters were not kept.

In the union's opinion, the main reasons for success in this election were:

1. Failure of GTES management to keep its promises to employees.

2. No written work rules resulting in disparity of treatment between employees.

3. Inequitable, undefined pay and benefit procedures that failed to keep pace with other GTE divisions.

4. $\quad$ Corporate downsizing and benefit cutbacks.

\section{THE COMPANY'S SIDE}

The essence of the GTES management side of the union organization drive was captured by the facsimile of the campaign button (see figure) supplied to the employees by management. During an interview with the author, Joe Buchanan, GTE Supply's manager of Supply Operations during the union campaign, said the attitude he conveyed to the employees throughout the campaign was that GTES was pro employee, not anti-union (Buchanan, 1994). His areas of responsibility, depicted in the organization chart on page one of Appendix Three, included both nonunion GTES employees and union TELCO employees working in the same facilities, sometimes under the same supervisor.

Prior to the January 1994 election, GTES employees were nonunion in the midst of union represented employees. Because of the nature of their work, both work groups had substantial interaction during the course of the workday. Consequently, both the union and nonunion workers knew each other's pay scales and benefit packages. Comparisons between the work groups were frequent and unpreventable.

Compounding this difficult environment were the following additional conditions present when Buchanan took over Tampa operations:

1. There was no human relations department or human relations manager on site. The HR department in the Dallas headquarters dictated all HR policies and procedures, and no avenue of communication with HR was available to the employees.

2. Pay inequity existed between the work groups. Additionally, the union employees transferred to nonunion GTES in early 1993 created pay inequities within the GTES work force.

3. A difficult, if not unintelligible, pay-for-performance plan, dictated by the Dallas HR department, was in place. 4. There was a lack of clear, formal work rules that contributed to disparity of treatment by supervisors.

Buchanan's initial focus was on correcting these problems. His task was made more difficult because he was initially responsible for seven states in the GTES South Area region and was on the road a great deal of the time. Additionally, his autonomy in making labor relations decisions was severely restricted by the dominance of the Dallas HR department.

His initial HR goals were to hire a Human Relations Manager in early 1993, to attempt to clarify the pay-forperformance plan for the employees, and to improve communication between the hourly employees through an open door policy and monthly employee meetings. The HR manager and improved communications were easily implemented and readily accepted by the employees. However, the merit pay plan was a difficult to understand matrix combining variable base-pay rates with a complex pay-for-performance plan that the employees did not comprehend, even after several meetings and communications to explain its function. 
Prior to receiving the notification of petition filing from the NLRB, Buchanan worked out a 5.5 percent acrossthe-board wage increase for the GTES employees. Additionally, the employees also received a three to five percent increase in their bonuses. While this was an improvement in the pay inequities between GTES and the other GTE organizations, it did not reduce confusion about the merit pay system nor did it cure the intra-organizational pay inequities created when the TELCO employees transferred to GTES. These issues still disturbed the hourly employees, and attempts to correct these inequities were in process at the time the NLRB petition was received at the GTES Tampa office.

With limited autonomous latitude and no pervious organization drive experience, Buchanan's initial reaction when he received the petition was to inform the corporate offices in Dallas. Corporate sent people from the HR department to "live in Tampa for the duration" (Buchanan, 1994). These individuals guided Buchanan and ran the campaign. No outside consultants or lawyers were hired; legal assistance came from lawyers on the GTE staff.

The company's initial campaign strategy was to schedule a series of captive audience meetings with its employees. Captive audience meetings are those held on company premises that employees are required to attend. These meetings were confined to the GTES employees, excluding TELCO employees who were already represented by the IBEW. Each meeting dealt with one of the following specific topics:

1. $\quad$ Setting the Tone for the Campaign

2. How Collective Bargaining Works

3. Union Issues

4. Election Procedures

Although each meeting was oriented towards a specific topic, the company used the meetings as forums to express its viewpoints, inform the employees of what they already had and the improvements that had been received in the recent past, rebut union claims, and answer the employees questions. During the first meeting the employees had virtually nothing to say, but during subsequent meetings they became more participative and many questions and complaints were raised. The predominant complaints focused on the pay plan procedures, seniority, and security. Copies of some of the presentation material used in these meetings can be found in Appendix Three, pages 8 to 20. These meetings were lead by different individuals including Buchanan, a corporate vice president from Dallas, and the corporate Director of Human Relations (Buchanan, 1994). In keeping with the "Pro-Employee" attitude described earlier, the company attempted to project a positive, upbeat attitude and avoid hostile confrontation during the course of the campaign. However, on two occasions conflicts arose, one of which lead to an unfair labor practice being filed by the IBEW with the NLRB. Because of the sharing of the facilities by both nonunion GTES employees and union Telco employees, Local 824 President Langlais had collective-bargaining-agreement contractually agreed to access to the facilities to talk with the people he represented under the TELCO contract, as long as he did not interfere with work. On November 10, 1993, Langlais entered the break room of the building which was occupied by both union and nonunion employees with union information and union handouts describing the employees rights, ostensibly to talk to the already unionized TELCO employees. When Buchanan was informed of the situation, he telephoned the corporate lawyer who was handling the campaign for instructions. The lawyer told him to remove Langlais from the facilities. Langlais, when he was requested to leave, stated he was allowed to be there per the terms of the collective bargaining agreement. However, Buchanan, following orders, insisted he leave the premises. Several days latter Gary Nelson, Asst. Business Manager for IBEW Local 824, filed an unfair labor practice against GTES stating "On or about November 10, 1993, the above-named employer restrained and coerced its employees in the exercising of their Section 7 rights, by prohibiting and preventing them from soliciting and discussing the union with a representative of the labor organization named below, during employees' non-working time" (United States of America, November 1993). According to Langlais, after he was escorted out of the facility he contacted the local attorney for TELCO and reminded him of the requirements of the contract. This individual contacted the attorney who had instructed Buchanan and corrected the situation, then informed Langlais he would not be interfered with again. The unfair labor practice charge was subsequently withdrawn. A copy of the unfair labor practice and withdrawal are in Appendix Three, pages 21 to 27. 
A second incident occurred on December 3, 1993, when Langlais and approximately fifteen other individuals entered the facility and started passing out union T-shirts in working areas. Some of the individuals entered the office area and stood in individual cubicle entrances, preventing the employees within the cubicle from passing. When Buchanan was informed of what was transpiring, he instructed the union individuals to confine themselves to areas they were authorized to be in, whereupon they departed the building. In response to several employees' complaints about being intimidated, Buchanan issued a letter to all employees telling them they could file a complaint with the NLRB if they desired (Buchanan, 1993). No complaints are part of the NLRB case record and no further incidents occurred.

Throughout the campaign the company tried to project a non-confrontational attitude towards the union, and to encourage the employees not to treat each other differently regardless of their union affiliation. During the captive audience speeches Buchanan stressed that whatever the outcome of the election, all employees would have to continue to work together for the company to remain productive. At the last captive audience speech held twenty-five hours before the election, he announced that regardless of the outcome, a pizza party would be held after the election for all GTES employees. This was another attempt to maintain unity among the work group. Despite these efforts, there has been some work group splitting along union/nonunion lines.

A greater problem was infighting among the pro union employees. Several of the original core committee employees were vying for union leadership positions within the company causing strife within the pro-union group. Additionally, there were several different negotiating agendas within the group causing additional conflict. As Buchanan expected, these problems resolved themselves as additional time passed and union elections/negotiations were completed.

\section{CONCLUSION}

Subsequent to receiving the third petition for election in November 1993, the HR department of GTES conducted focus group meetings to determine why the employees signed authorization cards. The following is a summary of their findings:

1. The number one reason for signing cards was the employees concern over job security and potential layoffs. Many employees believed that the union could save their jobs.

2. There was a substantial loss of trust in supervisors and/or management due to consistently unfilled commitments and untimely, ambiguous communications.

3. Employees were thoroughly confused by the merit pay system. Furthermore, they believed that the union had the ability to negotiate wage improvements for them that they were unable to do on their own. They felt they had no personal input into the process and that their wages were totally at the discretion of management.

4. Employees felt that seniority should be used for more than job placements or in determining layoffs. They wanted to see seniority tied into wages and benefits.

If management accepts the results of these meetings at face value they would be examining the symptoms of the problem and not necessarily understanding the underlying causes. The focus of the employees on the inequities of the merit pay system and concerns over security brings two motivational theories into consideration: Adams' Equity Theory and Maslow's Hierarchy of Needs.

The Equity theory is based on the simple premise that people want to be treated fairly (Adams, 1963). "Equity theory focuses on people's desire to perceive equity and avoid inequity" (Morehead, 1990). A person's assessment of inputs and outcomes for both themselves and others are based partly on objective data, such as wages, and partly on subjective data, such as valuations. Thus, the employees' expectations can be explained by the thusly: when an equitable situation is perceived, the person is motivated to maintain the status quo. However, if a person perceives inequity, they are motivated to reduce. The greater the perceived inequity, the greater the motivation. The GTES employees failure to understand the merit pay system and their proximity to unionized workers making more money under a much more easily understood wage scale enhanced the feelings of inequity, increasing their motivation to change the situation. Their solution to reduce inequity was to increase their own outcomes (wages/benefits) through unionization. This restored balance to their personal Equity Formula comparisons. The problem could have been avoided if management recognized 
the perceived inequities created by the merit pay plan and corrected them through one of the following:

1. Making the outcomes (wages) of the merit pay plan equal to those received by the employees who were covered under the union contract. The systems for achieving the wages do not have to be the same, but the employees must understand the functioning of the system and recognize that equal inputs will result in equal outcomes. If the merit pay plan did not provide for comparable outcomes, it should have been modified accordingly.

2. The simplest procedure would have been to abandon the merit pay plan and offer the employees of GTES a wage plan identical to the one in the union contract. This would have removed any possible feelings of inequity and eliminated the confusion that resulted from the merit pay plan. Furthermore, it would have given the employees an enhanced feeling of confidence in management's concern for their welfare. While this solution was simple and straightforward, it was not acceptable to GTES corporate management. On the day before the final election, Joe Buchanan suggested to the corporate HR manager that if the company won the election that the merit pay plan should be scrapped in favor of a plan comparable to the one in the contract, one that the employees could understand. The answer he received was an emphatic no. Apparently, there were hidden corporate or personnel agendas surrounding the merit pay plan which prevent the implementation of an alternative more acceptable to the employees. The merit pay plan is believed by local management to be the fundamental issue of union organizational campaigns at other GTES facilities.

The late psychologist, A.H. Maslow, described man's needs as a hierarchy, with satisfaction of lower order needs a prerequisite to the recognition of the next higher order need. Maslow's hierarchy defines the following five basic need classifications:

1. Physiological Needs-the need for food, water, clothing, shelter. This is the most basic need classification.

2. Safety Needs - the need for security, protection against arbitrary deprivation, danger and threat.

3. Belongingness Needs-the social needs of belonging, acceptance and association.

4. $\quad$ Esteem Needs - the need for recognition, respect, and confidence.

5. Self-Actualization Needs - the need to realize one's potential and achieve maximum creative potential.

According to Maslow, once a lower order need is satisfied, higher needs in the hierarchy become the individual's motivating factors. Therefore, it is the unsatisfied need that motivates human behavior. Since a satisfied need is no longer a motivation factor and man continues to be driven by needs, higher order needs must become the driving factors once previous need categories are fulfilled. However, if a lower order need returns to a state of dissatisfaction or concern, it once again becomes a primary motivating factor.

As indicated by their responses in the meetings discussed above, the layoffs at GTES in 1991 and the continued downsizing of GTE corporate-wide made the employees insecure and uncertain over the future of their jobs. Thus, security became a primary motivational factor. Employees believed the union could save their jobs. Arguments presented by Langlais that the company should "grow the business, not shrink the costs" undoubted heightened the employees insecurity and turned them towards the union for protection.

Two other problems the company had were poor communications between employees and management and lack of trust by the employees in what management told them. Although his predecessors caused these problems and Buchanan was correcting them, the situation was highly deteriorated by the time he got there. These are both complex issues, and must be dealt with continuously and consistently by effective management. By maintaining management credibility and using effective communications procedures

Although it is management's nature to resist unionization at all times and in all situations, the question arises in this case as to whether GTES Tampa was actually better off being unionized. The situation the company was in was nearly unmanageable from a labor-relations aspect. Both unionized and non-unionized employees shared the building. Some work groups contained both unionized and non-unionized employees. There had been two previous organizational drives. Local management did not have the autonomy to correct problem issues (merit pay system) and corporate management would not. The company was downsizing, and there were frequent transfers from the unionized divisions of the company 
into non-unionized GTES. These factors contributed to continuous labor strife. Through unionization, most of the problems created by these factors for management were eliminated. Additionally, local IBEW leadership appears to have had a progressive attitude to management-union relationships. Once any ill will remaining from the campaign dissipated, the situation for both management and the employees improved substantially.

\section{REFERENCES}

1. United States of America. (1993, November). National Relations Board Letter, NLRB to GTE Supply.

2. United States of America. (1996, January 6). National Relations Board - Tally of Ballots, NLRB to GTE Supply. Case No. 12-RC-7679.

3. Cihon, Patrick J. and Castagnera, James O. (1988), Labor Employment and Law - The Unionization Process (pp. 56-79). Boston: PWS-Kent Publishing Co.

4. $\quad$ Langlais, Guy (1994, February 2). IBEW Local 824 President, personal interview.

5. International Brotherhood of Electrical Workers. MEMO - What is the MEMO an Why Are We Here. IBEW printing office.

6. Holley, William H. and Jennings, Kenneth M. (1991). The Labor Relations Process (p. 134). Orlando: The Dryden Press.

7. $\quad$ Buchanan, Joe (1994, February 9). GTES Tampa Manager, personal interview.

8. J. Stacey Adams (1963, November). Toward an Understanding of Inequity. Journal of Abnormal and Social Psychology, 422-436.

9. United States of America (1993, November 18). National Labor Relations Board - Charge Against Employer. Case No. 12-RC-7679.

10. United States of America. (1985, May). Petition Form NLRB-502. Washington D.C., U.S. Government Printing Office.

11. Langlais, Guy A. (1993, December 20). Letter to GTE Supply Employees.

12. Langlais, Guy A. (1994, January 3). Letter to GTE Supply Employees.

13. Buchanan, Joe. (1993, December 6). Letter to Employees - Union Activity.

14. Moorhead, Gregory (1990). Organizational Behavior (pp. 155-156). Boston:Milffin Company.

15. Hughes, Charles L. (1979). Managing to Stay Non-Union (pp. 15-22). New York: Executive Enterprises Publications Co. 


\section{NOTES}

